(C) 1982 ISIJ

\title{
Measurement of Quasi-binary Interdiffusivities of Various Oxides in Liquid Slags
}

\author{
Yoshio Uкyо and Kazuhiro S. Gото
}

Synopsis :

( )uasi-binary interdiffusivities of several solute oxides in liquid $\mathrm{CaO}-\mathrm{SiO}_{2}-\mathrm{Al}_{2} \mathrm{O}_{3}$ slag of $4: 4: 2$ of charge weight ratio and liquid $\mathrm{Fe}_{2} \mathrm{O}_{3}-\mathrm{CaO}-\mathrm{SiO}_{2}$ slag of 2.5:3:4.5 of charge weight ratio equibriated with air were measured by using the diffusion couple method between 1350 to $1450^{\circ} \mathrm{C}$. After diffusion runs for 20 or $40 \mathrm{~min}$, the sample was quenched to glassy state and analyzed by a X-ray micro-analyzer. The quasi-binary interdiffusivities obtained from the penetration curves of totally 68 successful diffusion runs can be expressed by the following equations.

(a ) $40 \mathrm{wt} \% \mathrm{CaO}-40 \mathrm{wt} \% \mathrm{SiO}_{2}$

$$
\begin{aligned}
& \widetilde{D}_{\mathrm{P}_{2} \mathrm{O}_{5}}-2.16 \exp \left(\begin{array}{c}
55.0 \\
R T
\end{array}\right) \\
& \widetilde{D}_{\mathrm{Fe}_{2} \mathrm{O}_{3}}-5.45 \exp \left(\begin{array}{c}
66.8 \\
R T
\end{array}\right) \\
& \widetilde{D}_{\mathrm{TiO}_{2}}-2.30 \exp \left(\begin{array}{c}
58.5 \\
R T
\end{array}\right) \\
& \widetilde{D}_{\mathrm{MgO}}-3.27 \exp \left(\begin{array}{c}
23.2 \\
R T
\end{array}\right) \\
& \check{D}_{\mathrm{MnO}}=5.04 \exp \left(\begin{array}{c}
57.0 \\
R T
\end{array}\right)
\end{aligned}
$$

(b ) $25 \mathrm{wt} \% \mathrm{Fe}_{2} \mathrm{O}_{3}-30 \mathrm{wt} \% \mathrm{CaO}-45 \mathrm{wt} \% \mathrm{SiO}_{2}$

$$
\begin{aligned}
& \widetilde{D}_{\mathrm{P}_{2} \mathrm{O}_{5}}=3.42 \exp \left(-\begin{array}{c}
57.5 \\
R T
\end{array}\right) \\
& \widetilde{D}_{\mathrm{TiO}_{2}}=9.65 \exp \left(-\frac{79.6}{R T}\right) \\
& \widetilde{D}_{\mathrm{MnO}}=1.38 \exp \left(-\frac{34.1}{R T}\right) \\
& \widetilde{D}_{\mathrm{MgO}}=4.75 \exp \left(-\frac{22.5}{R T}\right) \\
& \widetilde{D}_{\mathrm{NiO}}=3.36 \exp \left(-\frac{50.9}{R T}\right)
\end{aligned}
$$

where quasi-binary interdiffusivities and activiation energies are given in the unit of $\mathrm{cm}^{2}$ per sec and $\mathrm{kcal}$ per mol, respectively.

Of a total 138 diffusion runs, only 68 samples gave normal penetration curves. Other unsuccessful samples contained many small gas bubbles.

\section{1. 緒言}

液体スラグおの種々の成分の払散挙動を調べることは 鉄鋼製鍊上極めて画要な脱硫や脱燐反応の解析にとつて 重要である。その理由は，脱硫や脱燐反応は，溶鉄-ス ラグ間に発生する代均一文応であり，多くの場合溶鉄あ るいはスラグ中の燐や硫黄の拡散が律速段階であると考 えられているからである，液体スラグ中の各成分の拡散 係数の測定は, Towers, PARIS, and Chipman ${ }^{1)}$ あるい は，斉藤，川令）らによつて放射性同位元素を用いる方 法が確汒されて以米，いくつかの測定例が報告されてい る3!。しかしながら拡散係数が得られている場合でもス ラグ組成は限られており，かつ測定者間のばらつきも大 きい，また酸化鉄を含さ製銅組成スラグ中の拡散係数の
測定は極めて少ないのが現状である.

そこで本研究では著者らが以前，製銑スラグ4)，製鋼 スラグ5) 系の相互拡散係数の測定に用いた拡散対法を用 いて，製銑スラグの基本系である $\mathrm{CaO}-\mathrm{SiO}_{2}-\mathrm{Al}_{2} \mathrm{O}_{3}$, お よび製鋼スラグの基本系である $\mathrm{Fe}_{2} \mathrm{O}_{3}-\mathrm{CaO}-\mathrm{SiO}_{2}$ スラ グ中の $\mathrm{P}_{2} \mathrm{O}_{5}, \mathrm{TiO}_{2}, \mathrm{Fe}_{2} \mathrm{O}_{3}, \mathrm{MgO}, \mathrm{MnO}$ などの鉄鋼 製錬上とくに重要と思われる成分の擬二元相互拡散係数 の測定を行つた。拡散対法を用いた拡散係数の測定にお いてはスラグ中に気泡が含まれると拡散対内が攪拌され 正しい測定結果が得られない場合が多い、本研究におい ても 138 回の拡散実験のうち良好な結果は 68 回であつ た. なお本論文で $\mathrm{TiO}_{2}, \mathrm{MgO}, \mathrm{Fe}_{2} \mathrm{O}_{3}, \mathrm{P}_{2} \mathrm{O}_{5}$ などの拡 散と表現しているのはこのような酸化物分子で拡散ジャ ンプしていることを意味せずあくまでも便宜的にそう表

顺和 56 作 12 月 7 几受付 (Received Dec. 7, 1981)

* 東京工策大兴大兴院(垷：ニューサウスウェールズ大学) (Graduate School, Tokyo Institute of Technology, Now The University of New South Wales)

*2 赖宗T: 箱大学: T:学部 Ph. D. 工博 (Faculty of Engineering, Tokyo Institute of Technology, 2-12-1 Ookayama Meguro-ku 152) 
現しているにすぎない．

\section{2. 実 験 方 法}

本研究では拡散係数の測定のために拡散対法を用い た. この方法は, 一様な太さの一端閉管の中で成分の濃 度がわずかに異なる試料を接触させて拡散対を構成し, 所定の温度まで加熱して拡散を行わせた後, 冷却し, 試 料の濃度分布を測定して払散係数を求める.

拡散実験は炭化ヶイ素を発熱体とした縦型の電気炉を 用いて行つた。拡散温度は 1350,1400 , および 1450 ${ }^{\circ} \mathrm{C}$ である. 炉芯管には, 内径 $42 \mathrm{~mm}$, 外径 $50 \mathrm{~mm}$, 長 さ $1000 \mathrm{~mm}$ のアルミナ管を用い, 電気炉の温度は Pt$\mathrm{Pt} \cdot 13 \% \mathrm{Rh}$ 熱電対を用いて測温し, 実験中は $\pm 2 \circ \mathrm{G}$ 以 内に保つた.

拡散に使用したスラグ組成は，（a ） $40 \mathrm{wt} \% \mathrm{CaO}-40 \mathrm{wt}$ $\% \mathrm{SiO}_{2}-20 \mathrm{wt} \% \mathrm{Al}_{2} \mathrm{O}_{3}$ と, この組成の大ラグにそれぞれ $6 \mathrm{wt} \% \mathrm{P}_{2} \mathrm{O}_{5}, 5 \mathrm{wt} \% \mathrm{TiO}_{2}, 5 \mathrm{wt} \% \mathrm{MgO}, 3 \mathrm{wt} \% \mathrm{Fe}_{2} \mathrm{O}_{3}$, $3 \mathrm{wt} \% \mathrm{MnO}$ を加えたスラグ，（b ） $25 \mathrm{wt} \% \mathrm{Fe}_{2} \mathrm{O}_{3}-30 \mathrm{wt}$ $\% \mathrm{CaO}-45 \mathrm{wt} \% \mathrm{SiO}_{2}$ と, この組成のスラグにそれぞれ $5 \mathrm{wt} \%$ の割合で $\mathrm{P}_{2} \mathrm{O}_{5}, \mathrm{TiO}_{2}, \mathrm{MnO}, \mathrm{MgO}, \mathrm{NiO}$ を加 えたスラグである. $\mathrm{P}_{2} \mathrm{O}_{5}$ は $\mathrm{Ca}_{3}\left(\mathrm{PO}_{4}\right)_{2}$ で加え, $\mathrm{P}_{2} \mathrm{O}_{5}$ と して $5 \mathrm{wt} \%, 6 \mathrm{wt} \%$ になるよらにした. これらのスラ グは次のようにして調整した， $\mathrm{CaO}$ は試薬特級炭酸力 ルシウムを $1100^{\circ} \mathrm{G}$ で熱分解することにより,その他は 市販の試薬特級を十分に乾燥して用いた．としてまず40 $\mathrm{wt} \% \mathrm{CaO}-40 \mathrm{wt} \% \mathrm{SiO}_{2}-20 \mathrm{wt} \% \mathrm{Al}_{2} \mathrm{O}_{3}, 25 \mathrm{wt} \% \mathrm{Fe}_{2} \mathrm{O}_{3}-30$ $\mathrm{wt} \% \mathrm{CaO}-45 \mathrm{wt} \% \mathrm{SiO}_{2}$ の組成になるように配合し，よく 混合した. さらにこの混合したものを 2 つに分け，一方 に拡散係数を測定しょうとする成分を添加し再びょく混 合する。

これらの粉末を，酸化鉄を含まないスラグは高純度ア ルミナるつぼ，酸化鉄を含むスラグは白金るつぼを用い て $1450^{\circ} \mathrm{C}$, 大気中で溶解した. 酸化鉄を含むスラグは 気相と平衡させるために $1 \mathrm{~h}$ 以上の時間をかけて溶解し た. 酸化鉄である $\mathrm{Fe}_{2} \mathrm{O}_{3}$ の一部は $\mathrm{FeO}$ に変化する が，LARSON CHIPMAN6) の結果を参考にすればその割合 は気相が空気の場合約 $18 \%$ である.

溶解したスラグは, 内径が約 $4.1 \mathrm{~mm}$ の黒鉛鋳型に 鋳込んで固形の棒状のスラグを得た.このようにして得 た固形の棒状スラグの表面をグラインダーで削り, 直径 が約 $3.9 \mathrm{~mm}$ になるよらにした. 次にこのスラグを長さ が約 $15 \mathrm{~mm}$ になるよらに切断し, その断面をエメリ一 紙で研磨し昖散用試料とした。拡散容器には大部分内径 $4 \mathrm{~mm}$, 外径 $6 \mathrm{~mm}$, 長さ $50 \mathrm{~mm}$ の高純度アルミナ管を 用いたが，酸化鉄を含さスラグの場合には，同じ大きさ
の高純度のマグネシアの容器をも用いた。

拡散実験は, 密度の小さいスラグをヒにし, 密度差に よる対流の影響が生じないよらにした，挑散管はあらか じめ所定温度に保持された電気炏にト部からゆつくり捚 入し，スラグの融点直上の温度で約 $5 \mathrm{~min}$ 保持し, 予 熱した後, 炬の均熱部分に挿人し抧散を行わせた。温度 が一定になつた時間を扒散の開始時閒とし, 所定の時問 拡散させた後すみやかに㭁から取り出し急冷する。急冷 後のスラグはすべて完全なガラス状態になることが絶対 条件であり，これが結晶状になると次の X-線マイクロ アナライザーによる分析が困難になる。昖散時間は主と して $20 \mathrm{~min}$ としたが, 得られる拡散係数の時間依存性 を調べるために，いくつかの試料については抁散時間を $40 \mathrm{~min}$ とした。測温は执散界面の寸ぐ横に設置した $\mathrm{Pt}$ - $\mathrm{Pt} \cdot 13 \% \mathrm{Rh}$ 熱電対を用いて行つた.

拡散を終えた試料は, 容器ごと樹脂に埋め巡み, ダイ アモンドカッターを用いて試料の中心を通るように切断 した，続いて，エメリー紙，バフを用いて研磨を行いX 線マイクロアナライザー (EPMA) で分析するために黑 鉛を真空蒸着した. 分析はすべて EPMAを用いて行 い, 分析条件は, 加速電压: $25 \mathrm{kV}$, 試料電流 $0.5 \times 10^{-7}$ A $100 \sim 200 \mu$ 間隔である. また分析は, 昖散係数を求 めようとする成分については行つたのみではなく、いく つかの試料ではその他の成分の分析も行つた。払散係数 を求めようとする成分の濃度とX線少度はほぼ比例する ことを分析に先だつて確かめた.

\section{3. 実 験 結 果}

Fig. 1 は, $\mathrm{CaO}-\mathrm{SiO}_{2}-\mathrm{Al}_{2} \mathrm{O}_{3}$ 久ラグけの $\mathrm{Fe}_{2} \mathrm{O}_{3}$ の 拡散実験の結果である。昖散温度は $1400^{\circ} \mathrm{C}$ ，昖散時間

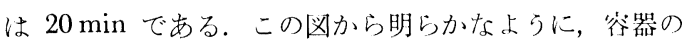
壁面に近い部分では凝固収縮によると思われる濃度分布 の乱れが喼められる.またこのような隹南付近は, 前報5! にも述べたように拡散容器であるアルミナあるいはマグ ネシアの溶解が起こる.このよらな部分からは, 正常な 濃度分布曲線を得ることはできない，䛤つて Fig. 1 の 中心部に見られるように, 将なな濃度分们を示す部分の みから濃度分布曲線を得た。元の例を Fig. 2 にホすす。 この図において縦軸は濃度比, 横軸は执散趾離である. なお，抎散距離は液休状態と固休状態との塑を密度の 測定值 ${ }^{778)}$ より補正した. したがつて $\mathrm{CaO}-\mathrm{SiO}_{2}-\mathrm{Al}_{2} \mathrm{O}_{3}$ の場合は約 $6 \%, \mathrm{Fe}_{2} \mathrm{O}_{3}-\mathrm{CaO}-\mathrm{SiO}_{2}$ の㘯令は約 $7 \%$, 固 体の場合より長い距離となつている。本研究において は, 昖散係数を求めようとする成分と他の成分の擬二元 相互拡散として取り扱い拡散係数を Matano-Boltzman 
の方法を用いて求めた，ある濃度 $C^{\prime}$ に打ける拡散俰数 Dは，次の上にして求められる.

$$
\tilde{D}=-\frac{1}{2 t}\left(\begin{array}{c}
d x \\
d C
\end{array}\right) C_{C^{\prime}} \int_{0}^{C^{\prime}} x d C
$$

ここで $t$ は拡散時閒 $(\mathrm{s}),(d x / d C)_{C^{\prime}}$ は濃度 $C^{\prime}$ における 拡散曲線の傾きである. $(d x / d C)_{\mathbf{0}}$ 及び $\int_{0}^{C^{\prime}} x d C$ はとれ ぞれ Fig. 2 に示す拡散曲線から求めることができる.

本研究では, Matano 界面の濃度における拡散俰数を算 出した. Table 1 および 2 に, 本実験の条件と得られた

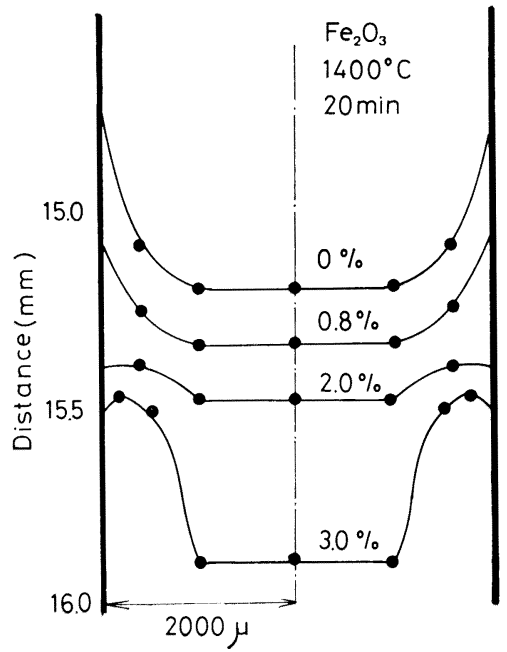

Fig. 1. $\mathrm{Fe}_{2} \mathrm{O}_{3}$ isoconcentration curves of diffusion couple near the initial interface after diffusion run for $20 \mathrm{~min}$ at $1400^{\circ} \mathrm{C}$.
拡散係数の值をまとめて示した．Fig. 3，Fig. 4は，得 られた抬散係数の平均值を温度の逆数に対してプロット したものである。 また，Table 3 および4 4 にはそれぞれ の成分の各温度において得られた擬二元相互拡散係数の 平均值を示した。これらの拡散係数の温度依存性をアー レニウス型の式で整理すると次のようになる.

(a) $40 \mathrm{CaO}-40 \mathrm{SiO}_{2}-20 \mathrm{Al}_{2} \mathrm{O}_{3}$

$$
\begin{array}{ll}
\widetilde{D}_{\mathrm{P}_{2} \mathrm{O}_{5}}=2.16 \exp (-55.0 / R T) & \left(\mathrm{P}_{2} \mathrm{O}_{5}: 3 \mathrm{wt} \%\right) \\
\widetilde{D}_{\mathrm{Fe}_{2} \mathrm{O}_{3}}=5.45 \exp (-66.8 / R T) & \\
& \left(\mathrm{Fe}_{2} \mathrm{O}_{3}: 1.5 \mathrm{wt} \%\right) \\
\widetilde{D}_{\mathrm{TiO}_{2}}=2.30 \exp (-58.5 / R T) & \left(\mathrm{TiO}_{2}: 2.5 \mathrm{wt} \%\right) \\
\widetilde{D}_{\mathrm{MgO}=3.27 \exp (-23.2 / R T)}(\mathrm{MgO}: 2.5 \mathrm{wt} \%) \\
\widetilde{D}_{\mathrm{MnO}}=5.04 \exp (-57.0 / R T) & (\mathrm{MnO}: 1.5 \mathrm{wt} \%)
\end{array}
$$

(b) $25 \mathrm{Fe}_{2} \mathrm{O}_{3}-30 \mathrm{CaO}-45 \mathrm{SiO}_{2}$

$$
\begin{array}{ll}
\widetilde{D}_{\mathrm{P}_{2} \mathrm{O}_{5}}=3.42 \exp (-57.5 / R T) & \left(\mathrm{P}_{2} \mathrm{O}_{5}: 2.5 \mathrm{wt} \%\right) \\
\widetilde{D}_{\mathrm{TiO}_{2}}=9.65 \exp (-79.6 / R T) & \left(\mathrm{TiO}_{2}: 2.5 \mathrm{wt} \%\right) \\
\widetilde{D}_{\mathrm{MnO}}=1.38 \exp (-341 / R T) & (\mathrm{MnO}: 2.5 \mathrm{wt} \%) \\
\widetilde{D}_{\mathrm{MgO}}=4.75 \exp (-22.5 / R T) & (\mathrm{MgO}: 2.5 \mathrm{wt} \%) \\
\widetilde{D}_{\mathrm{NiO}}=3.36 \exp (-50.9 / R T) & (\mathrm{NiO}: 2.5 \mathrm{wt} \%)
\end{array}
$$

単位は, $D$ は $\mathrm{cm}^{2} / \mathrm{s}$, 活性化エネルギーは $\mathrm{kcal} / \mathrm{mol}$ で ある，最後の項の各成分の濃度は， $\widetilde{D}$ 計算した位置の 濃度 (Matano 界面の位置の濃度) を示している。 ま た, 拡散時間は $20 \mathrm{~min} と 40 \mathrm{~min}$ の両方で行つたが, 得られた拡散俰数は実験誤差の範囲内で一致したので, 拡散係数に及ぼす時間の影響はないものと判断した.

両方のスラグに打いて, 各成分の拡散俰数の值に大き

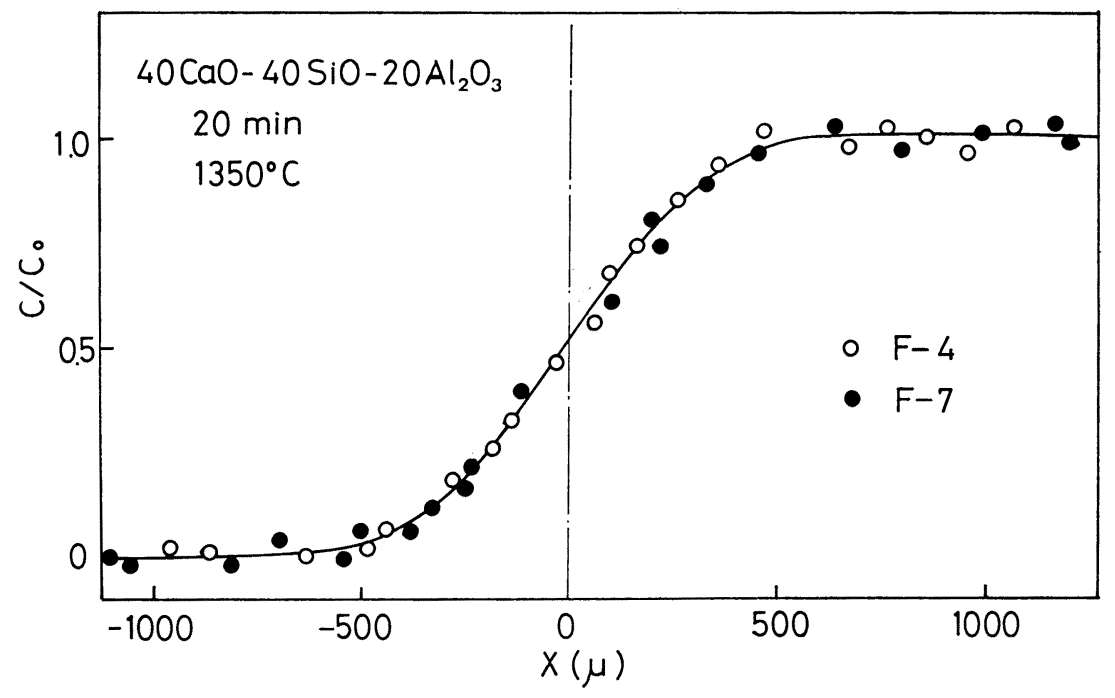

Fig. 2. Concentration penetration curves of $\mathrm{Fe}_{2} \mathrm{O}_{3}$ in $40 \mathrm{wt} \% \mathrm{CaO}-40 \mathrm{wt} \% \mathrm{SiO}_{2}-20 \mathrm{wt} \% \mathrm{Al}_{2} \mathrm{O}_{3}$ slag for $20 \mathrm{~min}$ at $1350^{\circ} \mathrm{C}$. 
Table 1. Conditions of diffusion experiment and all results obtained for $40 \mathrm{wt} \% \mathrm{CaO}-40 \mathrm{wt} \% \mathrm{SiO}_{2}-$ $20 \mathrm{wt} \% \mathrm{Al}_{2} \mathrm{O}_{3}$ melts.

\begin{tabular}{|c|c|c|c|c|}
\hline Element & Run No. & $\begin{array}{l}\text { Time } \\
(\mathrm{min})\end{array}$ & $\begin{array}{l}\text { Temp. } \\
\left({ }^{\circ} \mathrm{C}\right)\end{array}$ & $\begin{array}{c}D \\
\left(\mathrm{~cm}^{2} / \mathrm{s}\right)\end{array}$ \\
\hline $\mathrm{P}_{2} \mathrm{O}_{5}$ & $\begin{array}{l}P-1 \\
P-3 \\
P-4 \\
P-6 \\
P-9 \\
P-12 \\
P-13 \\
P-14 \\
P-15\end{array}$ & $\begin{array}{l}20 \\
20 \\
40 \\
20 \\
40 \\
20 \\
20 \\
20 \\
20\end{array}$ & $\begin{array}{l}1350 \\
1350 \\
1350 \\
1400 \\
1400 \\
1450 \\
1450 \\
1450 \\
1400\end{array}$ & $\begin{array}{l}3.5 \times 10^{-7} \\
4.8 \times 10^{-7} \\
2.0 \times 10^{-7} \\
7.0 \times 10^{-7} \\
9.8 \times 10^{-7} \\
1.8 \times 10^{-6} \\
9.0 \times 10^{-7} \\
1.2 \times 10^{-6} \\
5.0 \times 10^{-7}\end{array}$ \\
\hline $\mathrm{Fe}_{2} \mathrm{O}_{3}$ & $\begin{array}{l}F-2 \\
F-3 \\
F-4 \\
F-7 \\
F-8 \\
F-12 \\
F-14 \\
F-15\end{array}$ & $\begin{array}{l}20 \\
20 \\
40 \\
20 \\
20 \\
40 \\
20 \\
20\end{array}$ & $\begin{array}{l}1350 \\
1350 \\
1400 \\
1400 \\
1450 \\
1350 \\
1450 \\
1450\end{array}$ & $\begin{array}{l}7.8 \times 10^{-6} \\
\text { 3. } 0 \times 10^{-6} \\
\text { 3. } 1 \times 10^{-5} \\
9.9 \times 10^{-6} \\
9.5 \times 10^{-6} \\
4.7 \times 10^{-6} \\
1.5 \times 10^{-6} \\
\text { 3. } 0 \times 10^{-5}\end{array}$ \\
\hline $\mathrm{TiO}_{2}$ & $\begin{array}{l}\mathrm{T}-4 \\
\mathrm{~T}-5 \\
\mathrm{~T}-6 \\
\mathrm{~T}-9 \\
\mathrm{~T}-12 \\
\mathrm{~T}-14 \\
\mathrm{~T}-16\end{array}$ & $\begin{array}{l}20 \\
20 \\
20 \\
20 \\
20 \\
20 \\
20\end{array}$ & $\begin{array}{ll}1 & 350 \\
1 & 350 \\
1 & 400 \\
1 & 400 \\
1 & 450 \\
1 & 450 \\
1 & 450\end{array}$ & $\begin{array}{l}5.0 \times 10^{-7} \\
1.0 \times 10^{-7} \\
9.1 \times 10^{-7} \\
2.9 \times 10^{-7} \\
6.7 \times 10^{-7} \\
4.5 \times 10^{-7} \\
9.8 \times 10^{-7}\end{array}$ \\
\hline $\mathrm{MgO}$ & $\begin{array}{l}M-1 \\
M-2 \\
M-4 \\
M-6 \\
M-7 \\
M-9\end{array}$ & $\begin{array}{l}20 \\
20 \\
20 \\
20 \\
20 \\
20\end{array}$ & $\begin{array}{ll}1 & 350 \\
1 & 350 \\
1 & 400 \\
1 & 400 \\
1 & 450 \\
1 & 450\end{array}$ & $\begin{array}{l}\text { 4. } 0 \times 10^{-5} \\
\text { 1. } 0 \times 10^{-5} \\
\text { 3. } 1 \times 10^{-5} \\
\text { 2. } 3 \times 10^{-5} \\
\text { 3. } 0 \times 10^{-5} \\
5.5 \times 10^{-5}\end{array}$ \\
\hline $\mathrm{MnO}$ & $\begin{array}{l}\mathrm{Mn}-1 \\
\mathrm{Mn}-2 \\
\mathrm{Mn}-3 \\
\mathrm{Mn}-6 \\
\mathrm{Mn}-9 \\
\mathrm{Mn}-10\end{array}$ & $\begin{array}{l}20 \\
20 \\
20 \\
20 \\
20 \\
20\end{array}$ & $\begin{array}{l}1350 \\
1350 \\
1400 \\
1400 \\
1450 \\
1450\end{array}$ & $\begin{array}{l}\text { 5. } 0 \times 10^{-6} \\
\text { 1. } 4 \times 10^{-6} \\
\text { 8. } 0 \times 10^{-6} \\
\text { 6. } 0 \times 10^{-6} \\
\text { 1. } 3 \times 10^{-5} \\
\text { 6. } 0 \times 10^{-6}\end{array}$ \\
\hline
\end{tabular}

な差は認められずほぼ同じ大きさである. $\mathrm{P}_{2} \mathrm{O}_{5}$ や $\mathrm{TiO}_{2}$ のよらなネットワークフォーマーの性質を有する成分の 拡散係数は最も小さく，1350〜 $1450^{\circ} \mathrm{C}$ において $5.0 \times$ $10^{-7} \sim 1.0 \times 10^{-6} \mathrm{~cm}^{2} / \mathrm{s}, \mathrm{NiO}$ や $\mathrm{MnO}$ のような遷移金 属の酸化物は, $5.0 \times 10^{-6} \sim 1.0 \times 10^{-5} \mathrm{~cm}^{2} / \mathrm{s}$, アルカリ 金属の酸化物である $\mathrm{MgO}$ は, $1.0 \times 10^{-5} \sim 4.0 \times 10^{-5}$ $\mathrm{cm}^{2} / \mathrm{s}$ である.

本研究に拈いては，138 回の拡散実験を行つたが，そ のらち正常な濃度分布曲線が得られたのは68 回であ る. 失敗した試料の大部分は, 切断後試料中に気泡が含 まれていたことがわかり，この気泡によつてスラグが攪 判されてしまつたためであると考えられる.

\section{4. 考察}

\section{$4 \cdot 1$ 実験誤差}

抎散係数 $\widetilde{D}$ の相対䛊差は次のようにして与えられる。 $|\Delta D / D|=1 / 2\{|\Delta t / t|+\Delta A / A|+| \Delta B / B \mid\} \cdots(2)$ ここで, $A, B$ は(1) 式に拈ける $(d x / d C)_{C^{\prime}}, \int_{0}^{C^{\prime}} x d C$ を表している.前述したように, 拡散時間は拡散係数に注 とんど影響を与えないために $\Delta t / t=0$ である。また $\Delta A /$
Table 2. Conditions of diffusion experiment and all results obtained for $25 \mathrm{wt} \% \mathrm{Fe}_{2} \mathrm{O}_{3}-30 \mathrm{wt} \% \mathrm{CaO}$ $45 \mathrm{wt} \% \mathrm{SiO}_{2}$ melts.

\begin{tabular}{|c|c|c|c|c|}
\hline Element & Run No. & $\underset{\left({ }^{\circ}\right)}{\operatorname{Time}}$ & $\begin{array}{l}\text { Temp. } \\
\text { (min) }\end{array}$ & $\begin{array}{c}D \\
\left(\mathrm{~cm}^{2} / \mathrm{s}\right)\end{array}$ \\
\hline \multirow{7}{*}{$\mathrm{P}_{2} \mathrm{O}_{5}$} & $P-3$ & 20 & 1350 & 4. $1 \times 10^{-7}$ \\
\hline & $P-4$ & 20 & 1350 & 7. $9 \times 10^{-7}$ \\
\hline & $P-9$ & 40 & 1350 & $3.5 \times 10^{-7}$ \\
\hline & P-11 & 20 & 1400 & $9.5 \times 10^{-7}$ \\
\hline & $\mathrm{P}-12$ & 20 & 1400 & $6.5 \times 10^{-7}$ \\
\hline & $\mathrm{P}-15$ & 20 & 1450 & 2. $4 \times 10^{-6}$ \\
\hline & $\mathrm{P}-18$ & 20 & 1450 & $8.0 \times 10^{-7}$ \\
\hline \multirow{7}{*}{$\mathrm{TiO}_{2}$} & $T-2$ & 20 & 1350 & $4.5 \times 10^{-7}$ \\
\hline & $T-4$ & 20 & 1350 & $1.5 \times 10^{-7}$ \\
\hline & $T-6$ & 20 & 1400 & $9.1 \times 10^{-7}$ \\
\hline & $T-7$ & 20 & 1400 & 4. $9 \times 10^{-7}$ \\
\hline & $\mathrm{T}-8$ & 20 & 1450 & $1.5 \times 10^{-6}$ \\
\hline & $\mathrm{T}-10$ & 20 & 1450 & $8.0 \times 10^{-7}$ \\
\hline & $\mathrm{T}-11$ & 20 & 1450 & 1. $3 \times 10^{-6}$ \\
\hline \multirow{6}{*}{$\mathrm{MnO}$} & $\mathrm{Mn}-1$ & 20 & 1350 & 4. $2 \times 10^{-6}$ \\
\hline & $\mathrm{Mn}-2$ & 20 & 1350 & $9.8 \times 10^{-6}$ \\
\hline & $\mathrm{Mn}-5$ & 40 & 1400 & 5. $8 \times 10^{-6}$ \\
\hline & $\mathrm{Mn}-6$ & 20 & 1400 & 1. $0 \times 10^{-5}$ \\
\hline & $\mathrm{Mn}-9$ & 20 & 1450 & 1. $5 \times 10^{-5}$ \\
\hline & $\mathrm{Mn}-11$ & 20 & 1450 & $1.0 \times 10^{-5}$ \\
\hline \multirow{6}{*}{$\mathrm{MgO}$} & $M-4$ & 20 & 1350 & 1. $1 \times 10^{-5}$ \\
\hline & $M-5$ & 40) & 1350 & $2.8 \times 10^{-5}$ \\
\hline & $M-7$ & 20) & 1400 & 2. $0 \times 10^{-5}$ \\
\hline & $M-9$ & 20) & 1400 & $3.6 \times 10^{-5}$ \\
\hline & $M-10$ & 20 & 1450 & $2.3 \times 10^{-5}$ \\
\hline & $M-11$ & 20 & 1450 & $2.9 \times 10^{-5}$ \\
\hline \multirow{6}{*}{$\mathrm{NiO}$} & $N-1$ & 20 & 1350 & 2. $9 \times 10^{-6}$ \\
\hline & $\mathrm{N}-3$ & 20 & 1350 & $5.1 \times 10^{-6}$ \\
\hline & $N-6$ & 20) & 1400 & 9. $2 \times 10^{-6}$ \\
\hline & $N-7$ & 20) & 1400 & $3.8 \times 10^{-6}$ \\
\hline & $\mathrm{N}-9$ & 20 & 1450 & 1. $2 \times 10^{-6}$ \\
\hline & $N-10$ & 20 & 1450 & 6. $0 \times 10^{-6}$ \\
\hline
\end{tabular}

Table 3. Diffusion coefficients of some solute oxides in $40 \mathrm{wt} \% \mathrm{CaO}-40 \mathrm{wt} \% \mathrm{SiO}_{2}-20 \mathrm{wt} \% \mathrm{Al}_{2} \mathrm{O}_{3}$ melt.

\begin{tabular}{lccr}
\hline & \multicolumn{3}{c}{ Temp. $\left({ }^{\circ} \mathrm{C}\right)$} \\
\cline { 2 - 4 } & 1350 & 1400 & \multicolumn{1}{c}{1450} \\
\hline $\mathrm{P}_{2} \mathrm{O}_{5}$ & $3.4 \times 10^{-7}$ & $8.9 \times 10^{-7}$ & $1.3 \times 10^{-6}$ \\
$\mathrm{Fe}_{2} \mathrm{O}_{3}$ & $5.5 \times 10^{-6}$ & $1.5 \times 10^{-5}$ & $2.65 \times 10^{-5}$ \\
$\mathrm{TiO}_{2}$ & $3.0 \times 10^{-7}$ & $6.0 \times 10^{-7}$ & $7.0 \times 10^{-7}$ \\
$\mathrm{MgO}$ & $2.5 \times 10^{-5}$ & $2.7 \times 10^{-4}$ & $4.3 \times 10^{-5}$ \\
$\mathrm{MnO}$ & $3.2 \times 10^{-6}$ & $7.0 \times 10^{-6}$ & $9.5 \times 10^{-6}$ \\
\hline
\end{tabular}

Table 4. Diffusion coefficients of some solute oxides in $25 \mathrm{wt} \% \mathrm{Fe}_{2} \mathrm{O}_{3}-30 \mathrm{wt} \% \mathrm{CaO}-45 \mathrm{wt} \% \mathrm{SiO}_{2}$.

\begin{tabular}{cccr}
\hline & \multicolumn{3}{c}{ Temp. $\left({ }^{\circ} \mathrm{C}\right)$} \\
\cline { 2 - 4 } & 1350 & 1400 & \multicolumn{1}{c}{1450} \\
\hline $\mathrm{P}_{2} \mathrm{O}_{5}$ & $5.5 \times 10^{-7}$ & $8.0 \times 10^{-7}$ & $1.6 \times 10^{-6}$ \\
$\mathrm{TiO}_{2}$ & $3.0 \times 10^{-7}$ & $7.0 \times 10^{-7}$ & $1.2 \times 10^{-6}$ \\
$\mathrm{MnO}$ & $7.0 \times 10^{-6}$ & $8.0 \times 10^{-6}$ & $1.03 \times 10^{-5}$ \\
$\mathrm{MgO}$ & $1.8 \times 10^{-5}$ & $2.8 \times 10^{-5}$ & $2.6 \times 10^{-5}$ \\
$\mathrm{NiO}$ & $4.0 \times 10^{-6}$ & $6.5 \times 10^{-6}$ & $9.0 \times 10^{-6}$ \\
\hline
\end{tabular}

$A ， J B / B$ は正確に铎価することは㜀難であるが，いず れも $10 \%$ 程度であると見楨もられる。したがわて本研

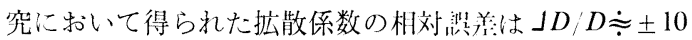
\%と考えられる.

\section{$4 \cdot 2$ 他の測定値との比較}

$4 \cdot 2 \cdot 1 \quad \mathrm{GaO}-\mathrm{SiO}_{2}-\mathrm{Al}_{2} \mathrm{O}_{3}$ スラグ

$\mathrm{CaO}-\mathrm{SiO}_{2}-\mathrm{Al}_{2} \mathrm{O}_{3}$ スラグ中に拈忛る各成分の拡散係 


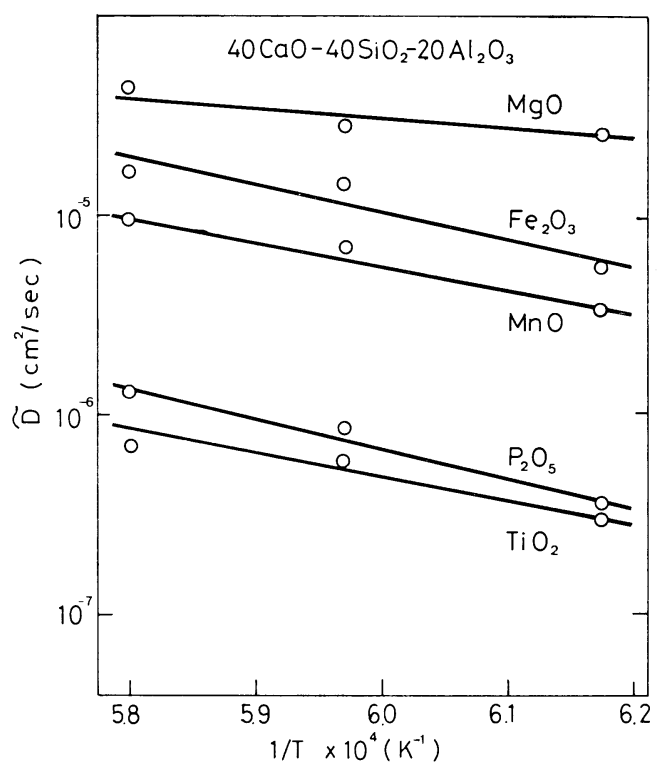

Fig. 3. Relation between reciprocal temperature and logarithm of quasi-binary diffusivities in 40 $\mathrm{wt}^{\circ} \% \mathrm{CaO}-40 \mathrm{wt} \% \mathrm{SiO}_{2}-20 \mathrm{wt} \% \mathrm{Al}_{2} \mathrm{O}_{3}$ slag. (This figure are obtained by totally 36 successful diffusion runs.)

数は比較的上く測定されているる ${ }^{3)}$. JOHNSON STARK, and

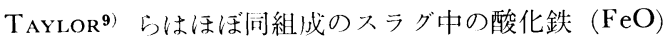
の擬二元相 Ii昖散係数を測定し $1400^{\circ} \mathrm{C}$ について, 1.0 $\times 10^{-5} \mathrm{~cm}^{2} / \mathrm{s}$ の佔を跟门して找り本研究結果と良く一致 する。しかし，見かけの活性化ェネルギーの值は 21.2 $\mathrm{kcal} / \mathrm{mol}$ であり本研究絬果の約 $1 / 3$ である. 本研究の 場苓，スラグは空短と头衡して扔り鉄イオンの大部分 は $\mathrm{Fe}^{3+}\left(\mathrm{Fe}_{2} \mathrm{O}_{3}\right)$ に, Johnson らの場合は, 不活性ガス 雲囲父と斗衡しており大部分 $\mathrm{Fe}^{2+}(\mathrm{FeO})$ になつている ものと考えられる。 $\mathrm{Fe}^{2+}$ に比べて $\mathrm{Fe}^{3+}$ の方が陽イオ

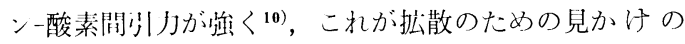
活性化エネルギーの差となつて現れるものと推定され る. $\mathrm{P}_{2} \mathrm{O}_{5}, \mathrm{TiO}_{2}$ の昖散係数の正確な測定值は見当たら ないので，部しい比較はできないが，同じネットワーク フォーマの性質を有する $\mathrm{Si}$ の目己拡散係数より 1 桁大 きく, $\mathrm{SiO}_{2}$ と $\mathrm{CaO}$ の擬 :元相台抾散係数とほぼ同じ 值である4)11)。 また, $\mathrm{MnO}$ は $\mathrm{Fe}_{2} \mathrm{O}_{3}$ とほぼ同じ拡散 係数である. $\mathrm{MgO}$ の抁散係数は，これらの成分の中で 最も大きく， Ca の门已昖散係数のほぼ5倍の大きさで ある。

$4 \cdot 2 \cdot 2 \quad \mathrm{Fe}_{2} \mathrm{O}_{3}-\mathrm{CaO}-\mathrm{SiO}_{2}$ スラグ

酸化鉄を含さスラグ中の执散係数の測定は，主として $\mathrm{Fe}^{12)}$ 14) $\mathrm{Ca}^{13)}$ のトレーサー払散係数, $\mathrm{Fe}$ とOの相互

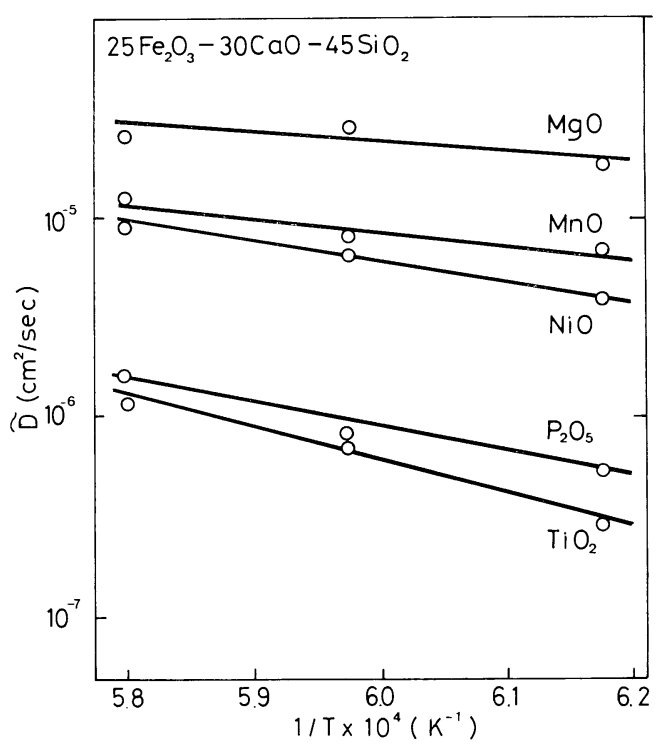

Fig. 4. Relation between reciprocal temperature and logarithm of quasi-binary interdiffusivities in $25 \mathrm{wt} \% \mathrm{Fe}_{2} \mathrm{O}_{3}-30 \mathrm{wt} \% \mathrm{CaO}-45 \mathrm{wt} \% \mathrm{SiO}_{2}$ equibriated with air. (This figure are obtained by totally 32 successful diffusion runs.)

拡散係数 15$)$ の測定などに限られており，最近になつて著 者らにより 3 元相互扗散係数 ${ }^{5)}$ の測定が行われたにすぎ ない。またそれらの測定は，文献 (5)(13)を除いて固体 鉄と平衡する条件下で測定が行われている. 森と鈴木 ${ }^{15)}$

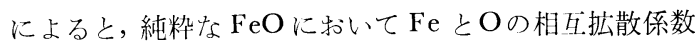
は, 酸素分压が増加すると小さくなり, Gото, KuRAHASHI, $\mathrm{SASABE}^{13)}$ によると, $\mathrm{CaO}-\mathrm{Fe}_{1-\mathrm{x}} \mathrm{O}-\mathrm{SiO}_{2}$ スラグ では, $\mathrm{Fe}, \mathrm{Ga}$ のトレーサー拡散係数は酸素分圧が増加 すると大きくなるなどの差違が認められる，従つて空気 と平衡する条件下で得られた本研究結果を直接他の測定 值と比較することは困難である.

$\mathrm{CaO}-\mathrm{SiO}_{2}-\mathrm{Al}_{2} \mathrm{O}_{3}$ スラグの場合と同様に, ネットワー クモディファイアーの性質の強い $\mathrm{MgO}, \mathrm{MnO}, \mathrm{NiO} の$ 拡散係数はネットワークフォーマーの性質の強い $\mathrm{TiO}_{2}$, $\mathrm{P}_{2} \mathrm{O}_{5}$ のそれよりも約 1 桁大きい. そして, $\mathrm{MgO}, \mathrm{MnO}$, $\mathrm{NiO}$ の昖散係数は固体鉄と平衡する $\mathrm{CaO}-\mathrm{SiO}_{2}-\mathrm{Fe}_{\mathrm{X}} \mathrm{O}$ スラグ中の $\mathrm{Fe}$ あるいは $\mathrm{Ca}$ のトレーサー拡散係数とほ ぼ同じ大きさである。また $\mathrm{CaO}-\mathrm{SiO}_{2}-\mathrm{Al}_{2} \mathrm{O}_{3}$ スラグな らびに空気と平衡する $\mathrm{Fe}_{2} \mathrm{O}_{3}-\mathrm{CaO}-\mathrm{SiO}_{2}$ スラグ中の各 成分の昖散係数は Fig. 3, Fig. 4 からも明らかなよう に大きな差は認められない。 


\section{5. 結言}

拡散対法を用いて，液体 $40 \mathrm{wt} \% \mathrm{CaO}-40 \mathrm{wt} \% \mathrm{SiO}_{2}-$ $20 \mathrm{wt} \% \mathrm{Al}_{2} \mathrm{O}_{3}$ ，ならびに空気と平衡する液体 $25 \mathrm{wt} \%$ $\mathrm{Fe}_{2} \mathrm{O}_{3}-30 \mathrm{wt} \% \mathrm{CaO}-45 \mathrm{wt} \% \mathrm{SiO}_{2}$ スラグ中における種々 の微量の酸化物の擬二元相互拡散係数を 1350 1 $450^{\circ} \mathrm{C}$ の温度範用で求めた．その結果, この 2 種類のスラグに おいて求められた拡散係数はほぼ同じ大きさであり, $\mathrm{P}_{2} \mathrm{O}_{5}$ や $\mathrm{TiO}_{2}$ のようなネットワークフォーマーの性質 の強い成分は, $5.0 \times 10^{-7} \sim 1.0 \times 10^{-6} \mathrm{~cm}^{2} / \mathrm{s}, \mathrm{NiO}, \mathrm{MnO}$, $\mathrm{Fe}_{2} \mathrm{O}_{3}$ の上うな遷移金属の酸化物は $5.0 \times 10^{-6} \sim 1.0 \times$ $10^{-5} \mathrm{~cm}^{2} / \mathrm{s}$ ，アルカリ金属の酸化物である $\mathrm{MgO}$ は, 1.0 $\times 10^{-5} \sim 4.0 \times 10^{-5} \mathrm{~cm}^{2} / \mathrm{s}$ である. 本研究においては, 138 回の実験のらち正常な濃度分布曲線が得られたのは 68 回である. 残りは， スラグ内に残存する気泡のため にスラグが攪判され正常な濃度分布曲線を得ることがで きなかつた。

酸化鉄を含むスラグの場合，トレーサー拡散係数，相 白拡散係数はともに気相中の酸素分圧に依存することが 報告されており，今後実操業などで必要とされる溶融鉄 と平衡する条件ドでの拡散係数の測定が望まれる。

本研究の費用の一部は石原・浅田研究助成金によるこ とを記し媣莧の感謝の意を表します。

\section{文献}

1) $H$. Towers, $M$. Paris, and J. Chipman: J. Metals, 5 (1953), p. 1455

2 ) 斎藤恒 (1953)，p. 434

3 ）特別報告書 No. 12，溶鉄 - 溶滓の物性值便覧 （日本鉄鋼協会溶銅・溶浮部会緎）(1971)

4 ) $H$. Sugawara, $K$. Nagata, and $K . S$. Goto: Met. Trans., 8B (1977), p. 605

5) $Y$. Uкyо and K.S. Goto: Met. Trans., 12в (1981), p. 449

6) H. Larson and $J$. Chipman: Trans. Met. Soc. AIME., 197 (1853), p. 1089

7 ) $A . G$. Thomas and $L$. $R$. Barret: J. Soc. Glass Tech., 18 (1965), p. 9

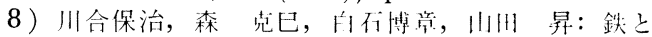
鐥， 62 (1976), p. 53

$9) R . F \cdot$ Johnson, $R \cdot A$. STARK, and $J$. TAYlor: Ironmaking and Steelmaking 1 (1974), p. 220

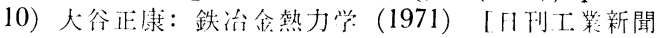
社.]

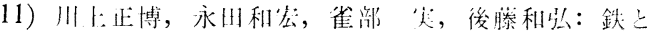
鋼，62 (1976), p. 1159

12) D. P. Agarwal and D. R. Gaskell: Met. Trans., 6B (1975), p. 263

13) K. S. Goto, T. Kurahashi, and $M$. Sasabe, Met. Trans., 8B (1977), p. 523

14) $L$. Y Ang, $C-Y$. Ghien, and $G$. Derge: J. Chem. Phys., 30 (1959), p. 1627

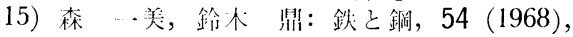
p. 1199 